\title{
The Constitutional Case for Independence
}

\author{
Aileen McHarg
}

\section{Introduction}

The 2014 independence referendum has been aptly described as an 'accidental referendum'. ${ }^{1}$ It was accidental, first, in the sense that the condition that made the holding of a referendum possible - the election in 2011 of a majority Scottish National Party (SNP) government at Holyrood - was just not supposed to happen. The electoral system for the Scottish Parliament was designed deliberately to avoid single-party majority government. More fundamentally, by responding to Scottish demands for self-government, devolution itself was expected - by some at least - to kill off demand for independence. ${ }^{2}$

In fact, the SNP's election victory did not signal any strong public desire for independence. In 2011, popular support for independence was only around 25 - 30 per cent, which was relatively low by historical standards, ${ }^{3}$ and the importance of the constitutional question compared to other electoral issues had also declined. ${ }^{4}$ The SNP therefore won the election in

\footnotetext{
${ }^{1}$ C. McCorkindale 'An Accidental Referendum', Scottish Constitutional Futures Forum Blog, 16 August 2013.

${ }^{2}$ Former Secretary of State for Scotland, George Robertson, is famously said to have claimed that 'Devolution will kill nationalism stone dead'.

${ }^{3}$ Ipsos Mori '35 Years of Scottish Attitudes Towards Independence', 15 March 2012, available at: $<$ https://www.ipsos-mori.com/researchpublications/researcharchive/2935/35-years-of-Scottish-attitudestowards-independence.aspx $>$. But nb support for a referendum on independence was higher: see What Scotland Thinks at <http://whatscotlandthinks.org/questions/do-you-support-or-oppose-a-referendum-on-scottishindependence\#line>.

${ }^{4}$ C. Carman, R. Johns and J. Mitchell, More Scottish than British: the 2011 Scottish Parliament Election (Palgrave Macmillan 2014) 87.
} 
spite of not because of its commitment to hold a referendum on independence; simply because 'most voters thought that the party would do a better job in office than its rivals'. 5 Indeed, the commitment to hold a referendum before commencing negotiations on independence, rather than after the conclusion of such negotiations, as had been party policy until 2000, was a deliberate - and highly successful - tactic to decouple electoral support for the SNP from support for constitutional reform. ${ }^{6}$

The second sense in which the 2014 referendum was accidental, then, was that it took place without any clear evidence of dissatisfaction with the constitutional status quo. ${ }^{7}$ This contrasted strongly with the 1997 referendum, when devolution was so clearly regarded as being (in John Smith's phrase) 'the settled will of the Scottish people' that many had argued that a referendum was unnecessary. ${ }^{8}$ Admittedly, the question of Scotland's constitutional future had been on the political agenda since 2007, when the then minority SNP government launched its National Conversation ${ }^{9}$ and the unionist parties responded by setting up the Calman Commission to review the operation of devolution. But the Calman Commission found that devolution was popular, and considered that it had operated largely successfully. ${ }^{10}$ Insofar as there was popular support for constitutional reform, therefore, it was for more

\footnotetext{
${ }^{5}$ R. Johns et al 'Constitution or Competence? The SNP's Re-Election in 2011' (2013) 61 Political Studies 158 at 158 .

${ }^{6}$ D. Torrance The Battle for Britain: Scotland and the Independence Referendum (Biteback Publishing 2013) 9

$-10$.

${ }^{7}$ McCorkindale (n 1).

${ }^{8}$ See A. King The British Constitution (Oxford University Press 2007) 290.

${ }^{9}$ Scottish Government Choosing Scotland's Future: A National Conversation: Independence and Responsibility in the Modern World (2007).

${ }^{10}$ Commission on Scottish Devolution Serving Scotland Better: Scotland and the United Kingdom in the $21^{\text {st }}$ Century (2009)
} 
devolution, rather than independence. However, the United Kingdom (UK) government was unwilling to countenance a second referendum question on further devolution - ostensibly, inter alia, because independence and further devolution were distinct constitutional issues, ${ }^{11}$ but also presumably because they thought that on a straightforward choice between independence and the status quo, independence would be comfortably defeated. In any case, as unionists frequently pointed out, further devolution was already being delivered via the Scotland Act 2012, which had been enacted in response to the Calman Commission's recommendations.

If by 2011 there was no strongly-felt constitutional grievance to which independence was the answer, nor was the subsequent referendum debate conducted primarily in constitutional terms. As other chapters in this volume have noted, ${ }^{12}$ once the debate moved beyond the early preoccupation with process issues, it was dominated by discussion of the substantive and particularly the economic - effects of independence on public policy in Scotland and on the lives of its residents. This again contrasts sharply with devolution, which proceeded on a clearly articulated analysis of the defects in Scotland's then governance arrangements and of the constitutional right of the Scottish people to secure enhanced self-government. ${ }^{13}$

\footnotetext{
${ }^{11}$ See I. McLean, J. Gallagher and G. Lodge Scotland's Choices: The Referendum and What Happens Afterwards (Edinburgh University Press 2013) 9 - 14.

${ }^{12}$ See Gallagher and Scott.

${ }^{13}$ See Campaign for a Scottish Assembly A Claim of Right for Scotland: Report of the Constitutional Steering Committee (1988); Scottish Constitutional Convention Towards a Scottish Parliament: Consultation Document and Report to the Scottish People (1989); Scottish Constitutional Convention Towards the Scottish Parliament: a Report to the Scottish People (1990; Scottish Constitutional Convention Scotland's Parliament: Scotland's Right (1995).
} 
The substantive nature of the referendum debate is largely attributable to the fact that the Scottish Government chose to base its case for constitutional change not around an existentialist nationalist claim - that Scotland, being a nation, should also be a state (although such arguments undoubtedly were made by independence supporters, for instance in claims that independence would make Scotland a 'normal' country), or that independence was necessary to preserve Scottish identity. Rather, the appeal was to a utilitarian nationalism, which saw independence as a tool to achieve a better society. ${ }^{14}$ This approach had the advantage of enabling many people who did not identify as Nationalists (at least with a capital $\mathrm{N}$ ), and who continued to feel some degree of Britishness, to support the Yes campaign on the basis that an independent Scotland would better able to deliver progressive policy outcomes. Its disadvantage was that it was vulnerable to counter-arguments that an independent Scotland would in fact be less able to achieve such policy outcomes, ${ }^{15}$ and to claims - made particularly by Labour politicians - that the constitutional debate was a distraction from the real business of improving the lives of Scottish people.

However, what these counter-arguments arguably failed fully to appreciate, and therefore adequately to address, was the fact that the instrumental case for independence was underpinned by a critique of Scotland's current governance arrangements. Except insofar as it was based on crude arguments about the assignment of tax revenues or the allocation of natural resources (arguments which were undoubtedly made, but which operated more as reasons why Scotland could be independent, rather why it should), the instrumental case

\footnotetext{
${ }^{14}$ See in particular N. Sturgeon 'Bringing the Powers Home to Build a Better Nation', Speech at Strathclyde University, 3 December 2012.

${ }^{15}$ See Gallagher, in this volume, and for a more optimistic assessment of the likely economic effects of independence, see Scott, in this volume.
} 
necessarily assumed that an independent Scotland would be able to govern itself differently and better than would be possible if it were to remain part of the UK.

Thus, contrary to initial impressions, there was a constitutional case for independence, which was made with varying degrees of explicitness. Moreover, this was a case which strongly echoed the constitutional case that had been made for devolution a generation earlier.

The aim of this chapter is to elucidate that constitutional case, which, I contend, was based around four sets of (intertwined, but conceptually distinct) arguments: about a democratic deficit; about effective governance; about the place of Scotland in the UK's territorial constitution; and about the constitution of an independent Scotland. The chapter also seeks to evaluate the strength of these arguments, particularly in the light of the referendum itself and subsequent events. It is important to appreciate that the referendum was not merely an opportunity to pass judgment on Scotland's constitutional arrangements, but was itself a constitutionally significant event which shaped perceptions of those arrangements. Thus, the referendum debate has served to focus and intensify constitutional dissatisfaction, which subsequent opinion polls and political developments suggest has certainly not weakened and may even have become stronger. ${ }^{16}$ The argument advanced in this chapter is that while none of the four constitutional claims made by Yes campaigners individually amounts to a compelling case for independence, cumulatively they seem likely to become harder to resist, particularly if post-referendum political and constitutional trends continue.

\section{A democratic deficit}

The most frequently invoked constitutional argument in favour of independence was the idea of a democratic deficit; in other words, that independence is the only way to guarantee that

\footnotetext{
${ }^{16}$ See What Scotland Thinks at <http://whatscotlandthinks.org/questions/how-would-you-vote-in-the-in-thescottish-independence-referendum-if-held-now-a\#line>.
} 
Scotland always gets the government it votes for. ${ }^{17}$ The claimed democratic deficit in Scotland's then system of government was of course one of the key justifications for the establishment of the Scottish Parliament. It was the election of four successive Conservative governments at Westminster between 1979 and 1997, during a period in which the party had only minority - and declining - electoral support in Scotland, ${ }^{18}$ which provided a clear rationale for devolution ${ }^{19}$ and persuaded a substantial majority of voters to support it. The ability of the government to impose unpopular policies (such as the poll tax) on Scotland came to be perceived not merely as 'the product of an occasional aberration by a particular British government [but as] a consequence of flaws in the system of government. ${ }^{, 20}$

However, the Scottish Government argued, devolution 'has only been a partial solution to the democratic deficit. ${ }^{21}$ Significant policy issues, on which Scottish preferences might diverge from those of voters in the rest of the UK (rUK), continue to be dealt with at UK level, and this necessarily must be the case even under the most generous devolution arrangements. Moreover, Scottish policy-making in devolved areas continues to be constrained by policy preferences at UK level, most significantly to the extent that the funding of the devolved institutions remains tied to expenditure levels in England via the Barnett formula, but also through UK government control of European Union (EU) and other international decisionmaking, and through the continued existence of GB-wide political party structures and policy communities. This was a point emphasized by the Scottish Government in the latter stages of

\footnotetext{
${ }^{17}$ See, eg, Scottish Government Scotland's Future: Your Guide to an Independent Scotland (2013) xii, 41.

${ }^{18}$ Conservative representation in Scotland declined from 22 (out of 71 seats) at the 1979 general election to just 11 seats in 1992 - House of Commons Library UK Election Statistics 1918- 2012, Research Paper 12/43 (2012)

11.

${ }^{19}$ See Kidd and Petrie, in this volume.

${ }^{20}$ Claim of Right (n 13) at para 8.4.

${ }^{21}$ Scotland' Future (n 17) at 333.
} 
the referendum campaign, when it highlighted the threat to the NHS in Scotland from the pursuit of privatization in England. Thus, independence was presented as a means of completing the democratic reform process begun by devolution. ${ }^{22}$

It is important to appreciate that the force of the democratic deficit argument - both as a justification for devolution and for independence - lies not merely in the temporary divergence of electoral majorities in Scotland and the UK as a whole (which could be resolved by a change of government at Westminster), but in the lack of control that Scottish voters have over the outcome of UK elections. The basic problem is the dominance of England, which has 84 per cent of the UK population. ${ }^{23}$ As the independence White Paper pointed out, this means that constituency results for Scotland rarely affect the outcome of UK general elections; in only two general elections held since 1945 have Scottish votes made a difference, and those governments held office for less than 26 months in total. ${ }^{24}$ This in turn means, it was claimed, that in order to win elections, parties have to present policies which appeal to voters in other parts of the UK whose voting patterns differ markedly from those in Scotland. $^{25}$

According to the 1988 Claim of Right - the document which may be regarded as providing the political foundation for devolution - the constitutional flaw in Scotland's machinery of

\footnotetext{
${ }^{22}$ See, eg, Scottish Government Scotland's Future: from the Referendum to Independence and a Written Constitution (2013) para 1.1.

${ }^{23}$ Office for National Statistics 'Mid-Year Population Estimates for the UK 2014', <http://www.ons.gov.uk/ons/rel/pop-estimate/population-estimates-for-uk--england-and-wales--scotland-andnorthern-ireland/mid-2014/mid-year-population-estimates-for-the-uk-2014.html> .

${ }^{24}$ Scotland's Future (n 17) at $333-334$.

${ }^{25}$ Scotland's Future (n 17) at 334.
} 
government was that it could only work within a limited range of election results. ${ }^{26}$ As McCrone puts it 'so long as Scotland and England voted more or less the same way, the constitutional anomaly whereby the United Kingdom always got a government the English voted for did not matter. ${ }^{27}$ But the anomaly became unsustainable when, from the 1960s onwards, voting patterns began to diverge. This divergence shows no signs of diminishing and, indeed, became even more pronounced at the 2015 UK general election. The SNP's near-clean sweep of the Scottish seats, and the refusal of the Britain-wide parties to countenance coalition, or even some lesser support arrangement with it, effectively locked out the overwhelming majority of Scottish MPs from participation in government. For the first time, this meant that there would be a democratic deficit in Scotland whichever party won most seats at UK level.

The key assumption which underpins the democratic deficit argument is that Scotland is a distinct political unit, and indeed the primary political unit in which democratic majorities are to be calculated. This is turn rests upon an assumption that Scotland is a nation with a right to political self-determination. In this basic sense, the instrumentalist case for independence is as much a nationalist position as the existentialist one. In fact, the claim that Scotland is a nation is not controversial. Nationhood in general is a concept which is notoriously difficult to define, since it rests on subjective perception rather than on purely objective criteria. But Scotland's claim to national identity is sufficiently well accepted, internally uncontested, and

\footnotetext{
${ }^{26}$ Claim of Right (n 13) at para 3.6.

${ }^{27}$ D. McCrone 'Scotland Out of the Union? The Rise and Rise of the Nationalist Agenda' (2012) 83 Pol Q 69 at 73.
} 
bolstered by sufficient historical, cultural, territorial, and institutional markers, that any questioning of Scotland's nationhood was confined to the fringes of the No campaign. ${ }^{28}$

However, the claim that Scotland, as a nation, should therefore enjoy political selfdetermination is more problematic. For some, the claim to national self-determination is inherently morally suspect. For instance, Joseph Weiler has argued that the secessionist claims of sub-state nations such as Scotland or Catalonia are 'ethically demoralizing'; they are, he claims, inherently associated with an atavistic, ethnic nationalism, and based on 'a seriously misdirected social and economic egotism, cultural and national hubris, and the naked ambition of local politicians. ${ }^{29}$ The UK - or Spain - as a multinational state therefore constitutes a morally superior site of political solidarity.

This kind of argument is arguably misconceived, at least in the Scottish case, because it misunderstands both the nature of the UK and the nature of Scottish nationalism. Keating argues that the UK is better understood as a 'plurinational' rather than a 'multinational' state. In other words, it is a state in which people have plural national identities, not merely one in which distinct national identities co-exist. ${ }^{30}$ 'Britishness' is therefore itself a national identity, albeit based on allegiance to a political order, rather than a common ethnic inheritance. However, the nationalism espoused by the SNP is equally a civic nationalism. It

\footnotetext{
${ }^{28}$ See, eg, the British nationalist blogger, Effie Deans, 'We Must Attack the SNP at its Roots', Lily of St Leonards blog, 18 April 2015, <http://effiedeans.blogspot.co.uk/2015/04/we-must-attack-snp-at-its-roots.html>; or mischievous suggestions that, if Scotland became independent, Orkney and Shetland should make their own claim to self-determination - e.g., Tavish Scott MSP, quoted in Tom Gordon 'Former Lib Dem Leader: "It's Shetland's Oil, Alex ...", The Herald, 17 March 2013.

${ }^{29}$ J.H.H. Weiler 'Editorial' (2012) 24 European Journal of International Law 909; 'Scotland and the EU: a Comment', Verfassungsblog, 8 September 2014.

${ }^{30}$ M. Keating Plurinational Democracy: Stateless Nations in a Post-Sovereignty Era (Oxford University Press 2001) $19,26-27$.
} 
is not a claim based on the inherent distinctiveness of the Scots as a people, but on their allegiance to a distinct political system. The argument made by critics of independence ${ }^{31}$ that there are only minor political differences between people in Scotland and the rUK is therefore broadly accurate ${ }^{32}$ but beside the point. What matters is the existence of a distinct Scottish political system. Institutionalized political communities take on their own dynamics; and it is undeniable that the terms of political debate in Scotland - for whatever reasons: different electoral systems; different voting patterns; different policy issues and/or policy contexts; different patterns of interest representation - have diverged from those which dominate at UK level. ${ }^{33}$

The choice between the UK and an independent Scotland is therefore one between competing versions of civic nationalism, or competing sites of political identity. ${ }^{34}$ In these circumstances, to prefer a priori the existing UK state to a putative Scottish state amounts simply to a bias in favour of the status quo, while to deny the relevance of nationhood to statehood altogether would be to ignore the reality of the existing state order. ${ }^{35}$

\footnotetext{
${ }^{31}$ See, e.g., Gallagher in this volume.

${ }^{32}$ Successive British and Scottish social attitudes surveys suggest only slight attitudinal differences between Scotland and the rUK - see <http://www.natcen.ac.uk> and <http://www.scotcen.org.uk>.

${ }^{33}$ See M. Keating and M. Harvey Small Nations in a Big World: What Scotland Can Learn (Luath Press 2014)

37 and ch 9. However, the degree of divergence should not be exaggerated, and Jackson also points out that there is greater diversity in political cultures within the rUK than a focus on the UK level might suggest - B. Jackson ‘The Political Thought of Scottish Nationalism' (2014) 85 Pol Q 50 at 53 - 54.

${ }^{34}$ Keating and Harvey Small Nations (n 33) at 18.

${ }^{35}$ Cf. N. Krisch 'Catalonia’s Independence: A Reply to Joseph Weiler’, EJIL: Talk!, 18 January 2013.
} 
In fact, for liberal nationalist theorists, 'self-determination is part of the normative content of nationality itself ${ }^{36}$ In other words, a claim to nationhood necessarily also entails an entitlement to collective self-government, arising from 'a respect for the freedom of individuals to choose their own lives and determine their political fate'. ${ }^{37}$ Crucially, however, effective self-government does not necessarily require full statehood. ${ }^{38}$ Nor is the claim an absolute one: particular self-determination claims may have to give way to competing principles. $^{39}$

In the Scottish case, the ability of a distinct national identity to flourish without independent statehood is readily apparent. Until relatively recently, there was no serious questioning of the legitimacy of the Union in Scotland. However, what Kidd has called 'banal unionism'40 did not mean the suppression of Scottish difference, nor the assimilation of Scottishness to Britishness. On the contrary, a commitment to the Union was consistent with the maintenance of substantial scope for Scottish self-government. The Union agreement itself preserved significant areas of autonomy in areas regarded as particularly important - in the law, the church, education, and social affairs, ${ }^{41}$ while the later growth of a centralized state

\footnotetext{
${ }^{36}$ Keating Plurinational Democracy (n 30) at 4. See also N. MacCormick Questioning Sovereignty (Oxford University Press 1999) ch 11; N. Walker ' Scottish Nationalism For and Against the Union State', in N. Walker (ed) MacCormick’s Scotland (Edinburgh University Press 2012) 168.

${ }^{37}$ Krisch (n 35).

${ }^{38}$ Keating Plurinational Democracy (n 30) at $7-8$.

${ }^{39}$ Keating Plurinational Democracy (n 30) at 28; MacCormick Questioning Sovereignty (n 36) at 174.

${ }^{40}$ C. Kidd Unions and Unionism (Cambridge University Press 2008).

${ }^{41}$ See L. Paterson The Autonomy of Modern Scotland (Edinburgh University Press 1994).
} 
apparatus in the late nineteenth and twentieth centuries was accompanied by considerable institutional recognition of Scottish distinctiveness. ${ }^{42}$

From one perspective, therefore, the advent of legislative devolution in 1999 might be seen as a relatively minor development in the self-government of Scotland within the Union, and one which carries no implications for any further developments towards independence. It merely added a representative and legislative body to the existing institutions of Scottish selfgovernment, and may be understood essentially as a defensive measure, aimed at protecting Scotland's distinct identity against perceived threats to its existence. The Claim of Right is in fact suffused with this kind of defensive language. ${ }^{43}$ On this view, the increased significance attached to separate political representation from the late 1960s onwards is explicable as a response to the relative decline of other carriers of national identity (due to processes of industrialization, urbanization, secularization, and the development of communications and democracy), ${ }^{44}$ and as a necessary bulwark against interference in Scottish civic life by overcentralizing governments insensitive to Scottish difference. ${ }^{45}$ But following devolution, with Scottish control over essential aspects of Scottish life now secured, and with no other obvious threats to Scottish identity or culture, a move to independence may be regarded as simply unnecessary. ${ }^{46}$

From another perspective, however, devolution in 1999 was indeed a constitutional turning point. Here, devolution may be understood, not as a defensive measure predicated on the

\footnotetext{
${ }^{42}$ See J. Mitchell The Scottish Question (Oxford University Press 2014).

${ }^{43}$ See, e.g., Claim of Right (n 13) at paras 2.2, 3.2, 6.10 and Epilogue.

${ }^{44}$ Mitchell Scottish Question (n 42) at 11.

${ }^{45}$ Mitchell Scottish Question (n 42) at 257.

${ }^{46}$ See, e.g., P. Jones 'Existential and Utilitarian Nationalism in Scotland', in K.P. Müller (ed) Scotland 2014 and Beyond: Coming of Age and Loss of Innocence (Peter Lang GmbH 2015) 152.
} 
insecurity of Scottish identity, but as a pure autonomy claim, deriving from a declining commitment to British identity, and a sense that distinct governmental institutions without a corresponding democratic base could no longer be seen as legitimate. On this alternative view, the case for self-government is not limited to areas of pre-existing Scottish difference or issues which are purely of concern to Scots. This was in any case always unconvincing as an explanation for the scope of devolution, and it becomes increasingly less persuasive as devolved competences expand. Instead, what is constitutionally significant about devolution is its basis in an explicit assertion of the sovereignty of the Scottish people (reinforced by popular consent through a referendum), and the platform it provides for the accentuation and proliferation of political, institutional, and policy difference, and the assertion of further autonomy claims. ${ }^{47}$ If based upon a pure autonomy claim, it is of course much more difficult to set coherent and durable limits to Scottish self-government. Indeed, the Scottish Constitutional Convention in its 1989 consultation document, Towards a Scottish Parliament - a document which endorsed the Claim of Right but which was subtly different in its analysis - expressly acknowledged that it followed from the principle of popular sovereignty that the Scottish people could legitimately choose to be independent (although it did not necessarily follow that they would or should do so), and it also accepted that it could be difficult to draw a hard line between the legislative competences of the Scottish Parliament and matters to be reserved to Westminster. ${ }^{48}$

The democratic deficit argument therefore has considerable normative force as a justification for independence and not merely for devolution. However, it still cannot be regarded as conclusive. There are two further problems to be addressed. First, as Keating points out, 'it

\footnotetext{
${ }^{47}$ S. Tierney 'Federalism in a Unitary State: A Paradox Too Far?' (2009) 19 Regional and Federal Studies 237 at $246-249$.

${ }^{48}$ (n 33) at 18 and 62.
} 
is a logical consequence of the doctrine of self-determination that its exercise may be limited by the equal rights of others', ${ }^{49}$ in this case the rights of those who maintain a British national identity.

This cannot be taken to mean that the desire of a majority of Scots to secede could be vetoed by a contrary desire of a British majority to maintain the territorial integrity of the UK, since that would be to subordinate the rights of a national minority to the wishes of the larger group. Indeed, it has never been seriously suggested in the UK context that issues of territorial self-determination are for anyone other than those living in the territory in question to determine (although the interests of the rUK in the process and consequences of such decisions have certainly been asserted). ${ }^{50}$ Instead, it means that the continued British identity of people living in Scotland has to be taken into account.

In fact, this is potentially problematic for proponents of independence, since it is clear that many people living in Scotland have a multiple national identities. Scottish Social Attitude Surveys continue to show that, if forced to choose between them, a clear majority will opt for a Scottish rather than a British identity (65 per cent and 23 per cent respectively in 2014). ${ }^{51}$ But on the more subtle 'Moreno' scale, a similar majority (63 per cent in 2014) will opt for some degree of shared Scottish and British identity, with only a minority ( 23 per cent in 2014) choosing an exclusively Scottish identity. ${ }^{52}$ Indeed, British identity seems to have

\footnotetext{
${ }^{49}$ Plurinational Democracy (n 30) 11.

${ }^{50}$ See A. McHarg 'The Independence Referendum, the Contested Constitution, and the Authorship of Constitutional Change', in Scotland 2014 and Beyond (n 46) at $242-246$.

${ }^{51}$ See What Scotland Thinks website at <http://whatscotlandthinks.org/questions/forced-choice-nationalidentity-5\#line>.

${ }^{52}$ See What Scotland Thinks website at <http://whatscotlandthinks.org/questions/moreno-national-identity5\#line>.
} 
become somewhat stronger in recent years, presumably as a direct result of the threat to that identity posed by the referendum itself.

To the extent that Britishness is still regarded as a relevant political identity, then the democratic deficit argument loses much of its force. If certain issues are regarded as being legitimately determined at UK level, then the fact that voters in Scottish constituencies sometimes end up with a UK government they did not support is no more constitutionally relevant than similar regional disparities in voting patterns elsewhere in the UK. ${ }^{53}$ Equally, if Scottish voters choose to support (regional) political parties which have no chance of forming a UK-wide government, then that is no more constitutionally problematic than a choice to support any other minority party.

However, one major difficulty with this argument is the assumption that Scottish and British national identities map unproblematically onto the distinction between devolved and reserved matters, or that they could ever do so. Political convergence and divergence between Scotland and the rUK is almost certain to cut across that boundary, wherever it is drawn, meaning that it is likely to be a continuing source of potential tension. Accordingly, unless territorial difference on reserved matters, as well as devolved matters, is handled carefully, there is an ongoing risk that policy difference on reserved matters may escalate into a legitimacy deficit, particularly if the parties in power at UK and/or Scottish level have a political interest in provoking conflict. ${ }^{54}$

Another problem is that national (political) identity is clearly not fixed. While the independence referendum may have had the effect of strengthening British identity, it has

\footnotetext{
${ }^{53}$ See, eg, K. Armstrong 'Political Representation at Holyrood Would Suffer Under Independence', The Herald, 29 August 2014.

${ }^{54}$ See J. Mitchell ‘Devolution's Unfinished Business' (2007) 77 Pol Q 465 at 470.
} 
also further embedded Scotland rather than the UK as the main political frame of reference. The referendum debate was emphatically a Scottish debate: it was a debate conducted within Scotland, with limited and largely unhelpful input from the rUK; and it was a debate about the future of Scotland, and the best interests of the Scottish people, not one about the UK. ${ }^{55}$ As more power is devolved to Scotland in the wake of the referendum, the political salience of Scotland is likely to increase, and that of the UK to decrease, even further. Indeed, there are already signs that Scottish politics are beginning to trump UK politics - for instance, the willingness of a majority of Scottish voters at the 2015 general election to vote on Scottish rather than British lines, ${ }^{56}$ and the prominence of devolved matters such as health in preelection debates, or the fact that the Scottish Labour party has felt the need to differentiate itself from the UK party on a reserved matter such as the renewal of Trident ahead of the 2016 Holyrood election.

As the political relevance of Britishness declines, it also becomes vulnerable to the argument that there are ways of giving expression to it other than through continued common statehood. For instance, the Scottish Government during the referendum campaign sought to recast Britishness as a geographical and cultural rather than a political identity, and to stress

\footnotetext{
${ }^{55}$ See A. McHarg 'A Tale of Two Constitutions' Scottish Constitutional Futures Forum blog, 16 December 2013; A. McHarg 'Has the United Kingdom Had a Good Referendum?’ 14 June 2014.

${ }^{56}$ Whereas the contrasting results of the 2007 and 2011 Scottish Parliament elections, on the one hand, and 2010 UK general election, on the other, suggested a significantly greater willingness to vote for the SNP in Scottish rather than UK elections, the SNP's vote share at the 2015 UK general election (50\%) was its highest ever. Survey evidence suggests that the SNP are most trusted to work in the long-term interests of Scotland by supporters of all parties; and preliminary analysis of the 2015 election also suggests a spillover effect from the independence referendum. See D. McCrone Changed Utterly (2015), available at: $\underline{\text { http://www.sps.ed.ac.uk/staff/sociology/mccrone_david }>; ~ E . ~ F i e l d h o u s e ~ T h e ~ B r i t i s h ~ E l e c t o r a t e ~ i n ~ 2015: ~ t h e ~}$ Fragmentation of Britain's Party System (2015), available at: 〈www.britishelectionstudy.com〉.
} 
the significant ties that would remain between Scotland and the rUK notwithstanding the ending of the political union between them. ${ }^{57}$ Again, therefore, without careful attention to the continued supports for political solidarity across the United Kingdom, the democratic argument for independence is likely to become stronger.

However, the second reason why the democratic argument for independence cannot be regarded as compelling is because the empirical evidence suggests that perceptions of identity are not the sole factors determining people's constitutional preferences. Post-referendum survey evidence shows that, while people with a strong Scottish identity were more likely to vote Yes, and people with a strong British identity to vote No, a commitment to the Union was not the decisive reason why independence was rejected. Instead, it was concerns about the risks and uncertainty of independence that were most important. ${ }^{58}$ What this indicates is that while democratic arguments are clearly important, they are not the only relevant factor in the design of satisfactory constitutional arrangements.

\section{Effective governance}

In fact, the democratic argument for independence was combined with a second argument about effective governance. The claim was, as Alex Salmond put it during his first televised

\footnotetext{
${ }^{57}$ See Scotland's Future (n 17) at $213-216$.

${ }^{58}$ See Lord Ashcroft's post-referendum poll - <http://lordashcroftpolls.com/2014/09/scotland-voted/>; and preliminary data from ESRC study post-referendum study -

$<$ http://centreonconstitutionalchange.ac.uk/sites/default/files/Scottish\%20Referendum\%20Study\%2027\%20Mar ch\%202015.pdf>.
} 
debate with Alastair Darling, that '[n]o one will do a better job of running Scotland than the people who live and work in Scotland., 59

Insofar as 'better government' means the pursuit of policies that the people of Scotland want, the claim that independence will lead to better decision-making may be regarded simply as a variant of the democratic deficit argument. However, understanding better government to be concerned, not only with the ends of public policy, but also with the means to those ends, it is conceptually separate: an argument about governmental capacity, rather than legitimate authority.

Once again, this echoed similar arguments made by advocates of devolution. For instance, the Scottish Constitutional Convention claimed that 'there is every reason to expect that the people of Scotland will tackle issues that confront them more effectively than Westminster acting remotely in their stead. ${ }^{60}$ The Scottish Government asserted - and the No campaign did not seek to deny - that devolution had been good for Scotland. ${ }^{61}$ Once again, therefore, the independence case sought to build upon existing support for devolution, essentially to argue that 'completing' the powers of the Scottish Parliament would also be good for Scotland. In support of this claim, the Scottish Government made reference to the greater flexibility and policy coherence that would come from having access to a full set of legal competences and policy levers; the greater ability to tailor policy measures specifically to Scottish needs; and the advantages arising from the smaller scale of government in Scotland,

\footnotetext{
59 'Scottish Independence: Salmond and Darling Clash in TV Debate', BBC News, 5 August 2014, <http://www.bbc.co.uk/news/uk-scotland-28649354>. See also Scotland's Future (n 17) at ix, 40; N Sturgeon 'The Constitutional Future of an Independent Scotland', speech at the University of Edinburgh, 16 June 2014. 
such as greater agility, accessibility, and shorter lines of communication, the more manageable scale of policy challenges, and greater scrutiny of policy delivery. ${ }^{62}$

In fact, academic analysis does support the view that small states can be more effective than larger ones, ${ }^{63}$ although Keating and Harvie are careful to emphasize that their success is dependent not simply upon their size, but upon the adoption of modes of governance appropriate to their particular circumstances: 'small-state governments are not merely largestate ones at a reduced scale but need qualitatively different structures and skills. ${ }^{, 64}$

However, the bigger problem for advocates of independence is that it is patently not always true that smaller governmental units are more effective. On the contrary, there are numerous reasons why the pooling of sovereignty in larger political units may lead to better policy outcomes. These include economies of scale - in particular, increased policy-making and regulatory capacities, ${ }^{65}$ and a greater ability to manage physical and economic risks by pooling and sharing resources over a larger population base ${ }^{66}-$ as well as policy spill-overs and externalities, which create co-ordination and collective action problems in the absence of joint decision-making machinery. In addition, independent states face external constraints through international law and the exposure to international markets - which bear particularly heavily on small states, and from which they may be more effectively shielded as a sub-state unit in a larger entity. ${ }^{67}$ In short, de jure power does not always amount to de facto power.

\footnotetext{
${ }^{62}$ See National Conversation (n 9) at ix, 9; Scotland's Future (n 17) at 48, 360.

${ }^{63}$ See Keating and Harvie Small States (n 33) at ch 3.

${ }^{64}$ Keating and Harvie Small States (n 33) at 69.

${ }^{65}$ Keating and Harvie Small States (n 33) at 68.

${ }^{66}$ See Gallagher in this volume.

${ }^{67}$ The issue of whether an independent Scotland would be able to continue to charge university tuition fees to rUK students, but not to Scottish-domiciled students is a good example of this.
} 
In practice, the desirability of continued integration was accepted by the Scottish Government, which advocated a model of independence which assumed, not isolation, but substantial co-operation with other states, through membership of the European Union, NATO, and other international organizations, and particularly through close ongoing ties with the rUK on a transitional or more permanent basis. The latter included a currency union, a single energy market, a shared head of state, defence co-operation, shared financial regulation, a common travel area, reciprocal citizenship and voting rights, shared social security administration, co-ordinated transport networks, and shared scientific, technical, and research programmes. ${ }^{68}$

Though frequently derided by No campaigners as amounting to 'independence lite' - a mere tactic designed to reassure risk-averse voters that nothing much would change upon Scotland becoming independent ${ }^{69}$ - and rejected by the UK government as promising a greater degree of inter-state co-operation than was to be found anywhere in the world, ${ }^{70}$ this was arguably a sophisticated attempt to come to terms with the conditions of 'post-sovereignty' ${ }^{71}$ In other words, the Scottish Government arguably had a far better understanding than their critics of the inevitable constraints upon the autonomy of states in an increasingly globalized world, and of the non-categorical nature of contemporary statehood. ${ }^{72}$

\footnotetext{
${ }^{68}$ Scotland's Future (n 17).

${ }^{69}$ See Jackson Political Thought (n 33) at 55.

${ }^{70}$ HM Government United Kingdom, United Future: Conclusions of the Scotland Analysis Programme $(\mathrm{Cm}$ $8869,2014)$ para 1.15.

${ }^{71}$ SNP thinking on this issue was strongly influenced by Neil MacCormick - see Questioning Sovereignty (n 36).

${ }^{72}$ See Walker Scottish Nationalism (n 36) at 187; Mitchell Scottish Question (n 42) at 277, 279.
} 
However, in its acceptance that sovereignty is not an absolute, but a matter of degree, the independence case inevitably became vulnerable to the argument that an appropriate blend of autonomy and inter-dependence could more satisfactorily be achieved through a constitutional arrangement short of full statehood ${ }^{73}$ - and without the rupture and transitional costs that independence would necessarily entail. ${ }^{74}$ Indeed, by the time of the referendum vote, it was just this sort of arrangement that the No campaign purported to be offering in the form of enhanced devolution within a reformed Union.

Two issues are particularly problematic for advocates of independence. The first is the argument that any sharing of sovereignty in the interests of effective decision-making would reintroduce a democratic deficit, because Scottish voters would be unable fully to control joint decision-making institutions. Indeed, arguably the democratic problems associated with inter-governmental decision-making are worse than any legitimacy deficit within the Union, insofar as joint decision-making is not subject to any direct parliamentary oversight (or in the case of the EU, only to weak parliamentary involvement), and executive decision-making in the field of inter-governmental relations is notoriously difficult to hold to account. ${ }^{75}$

There are several possible responses to this criticism. One is to accept that there are necessary trade-offs between democracy and effective government. However, just because

\footnotetext{
${ }^{73}$ See Walker Scottish Nationalism (n 36) and in this volume.

74 'A constitutional rupture followed by agreement would be a very different matter politically from an internal constitutional reform. It would create antagonisms and polarize opinion forcing politicians to stress the dividing line between independence and less radical options rather than the continuum between them. This could hamper cooperation in building new forms of partnership' - M. Keating The Independence of Scotland: Self-Government and the Shifting Politics of Union (Oxford University Press 2009) 140.

${ }^{75}$ See A. McHarg 'Scotland and the United Kingdom', in G. Hassan and J. Mitchell After Independence (Luath Press Limited 2013).
} 
some limits on sovereignty are acceptable, it does not follow that all are. It is not, therefore, a contradiction to choose to end one Union while maintaining others or entering into new cooperative arrangements. A second response is that any assessment of the implications of independence for democracy has to look at the quality of democratic engagement achievable under different constitutional scenarios and not merely at its formal extent. ${ }^{76}$ For instance, for many supporters of independence, the loss of formal democratic control over, say, monetary policy, was a price worth paying for independence plus a currency union because they did not believe that Scottish voters currently exercise meaningful control in this area given both the general arguments about the democratic deficit in reserved decision-making, discussed above, and the fact that monetary policy is in any case subject to only limited political control. ${ }^{77}$

A final response is to point out that it is only independent statehood that places the choice in the hands of the Scottish people to decide when and to what extent they want to share power with others. ${ }^{78}$ This may be argued to be an important democratic gain from independence because the relative advantages and disadvantages of autonomy and co-operation are likely to change, both over time and from issue to issue. While functional arguments can be made within a system of multi-level governance about the level at which particular powers are best exercised, these arguments are inherently contestable, both because conditions change and because functional arguments ultimately cannot be divorced from values: where powers are best exercised depends at least in part on what you want to do with them. ${ }^{79}$ Thus, for

\footnotetext{
${ }^{76}$ Cf MacCormick Questioning Sovereignty (n 36) at $133-134$.

${ }^{77}$ See, eg., R. McAlpine 'Is Someone Offering Us a Democratic Monetary Policy', The Jimmy Reid Foundation, 29 May 2012, available at: <http://reidfoundation.org/2012/05/is-someone-offering-us-a-democratic-monetarypolicy/>.

${ }^{78}$ Scotland's Future (n 17) at 43.

${ }^{79}$ See Keating Independence (n 74) at ch 7.
} 
example, the rationale for the Union has clearly changed over time, from an initial concern with trade and security, through a common commitment to empire and the Protestant religion, to a more recent concern to ensure a high standard of social protection through a common Welfare State - a commitment which itself is now arguably on the wane. ${ }^{80}$ Similarly, even those functions which, it is generally agreed, would have to be retained at UK level within any continuing Union - borders and citizenship; foreign affairs and defence; a common currency and single market - are subject to a range of external constraints and co-operative arrangements, which highlight the contingency of any territorial division of powers. ${ }^{81}$ Accordingly, any attempt to fix the limits of autonomous Scottish decision-making may itself be regarded as undemocratic, with only independent statehood ensuring that the people of Scotland remain in control of decisions as to how their interests are best advanced.

This, however, leads to a different objection to the independence case, namely that a relationship based on self-interest is necessarily less satisfactory than one based on the solidarity that comes from membership of a common political unit. ${ }^{82}$ This was an argument strongly advanced by the UK government, which argued that '[c]o-operation between states is profoundly different from being part of one state. ${ }^{83}$ Any post-independence co-operation would, it stressed, require to be in the mutual interest of both Scotland and the rUK; ${ }^{84}$ and, it suggested, it would in all likelihood not be in the interest of the rUK to co-operate to the degree proposed by the Scottish Government.

\footnotetext{
${ }^{80}$ T. Mullen 'The Scottish Independence Referendum 2014' (2014) 41 JLS 627 at 637.

${ }^{81}$ See Scottish Government National Conversation (n 9) at 8.

${ }^{82}$ See in particular Gallagher in this volume; see also Jackson Political Thought (n 33) at $55-56$.

${ }^{83}$ Scotland Analysis: Conclusions (n 70) at para 1.16.

${ }^{84}$ Scotland Analysis: Conclusions (n 70) at paras 1.16-1.17.
} 
To some extent, the UK Government's attitude to post-independence co-operation might be thought to have lacked credibility; ${ }^{85}$ a position adopted for tactical reasons which, as the history of British relations with the Republic of Ireland may suggest, might have changed once faced with the reality of independence. ${ }^{86}$ However, the more serious underlying point is that a relationship based on self-interest, where either party may at any time choose to withdraw from it, is inherently unstable, and not therefore conducive to the making of necessary compromises. The acceptance of permanent restrictions on sovereignty sacrificing the right to 'exit' in return for the exercise of 'voice' in a larger organization ${ }^{87}$ may therefore be a necessary price to pay for deeper and more meaningful co-operation.

Again, a number of responses are possible. Once again, the difficulty is to find a way of dividing powers that will prove to be stable and mutually acceptable. Approaching the issue from the perspective of what powers must be retained at the centre in order to maintain solidarity across the Union provides a decision-making criterion, but it does not necessarily make it any easier to agree upon the answer. This is clearly illustrated by post-referendum disputes over the acceptable extent of fiscal and welfare devolution, and over the acceptable degree of variation in the provision and protection of fundamental rights. It also remains necessary to reassure Scots that they do have a meaningful voice in the exercise of reserved powers. This leads to the broader point that solidarity is not just a question of where powers are exercised, but also how they are exercised. Solidarity may be undermined within a political union by political behaviour which weakens common commitments - for instance, attacks on welfare provision, or erosion of citizenship rights - or which stokes resentment

\footnotetext{
${ }^{85}$ See Mitchell Scottish Question (n 42) at 278.

${ }^{86}$ See McHarg, Scotland and the UK (n 75).

${ }^{87}$ Albert O. Hirschman Voice, Exit and Loyalty: Responses to Decline in Firms, Organizations and States (Harvard University Press 1970).
} 
about perceived unfair treatment of certain territorial groups - such as more generous public spending in Scotland enabled by an unequal funding formula. ${ }^{88}$ Finally, if the threat of exit is a destabilizing factor in relationships between states, it must also remain a problem in any UK constitutional order in which the right of the Scottish people (or other national groups) to self-determination is taken seriously. ${ }^{89}$ This brings us to the third element of the constitutional case for independence, which is the problematic nature of the UK's territorial constitution.

\section{The United Kingdom's territorial constitution}

The argument that aspirations for greater Scottish autonomy can be more satisfactorily accommodated within a reformed Union than through independence itself involves a constitutional claim. It must assume that a constitutional settlement can be reached which provides adequate recognition for Scottish autonomy and territorial diversity, yet which ensures sufficient constitutional cohesion to legitimate UK-level decision-making and hold the state together over the long term. Part of the case for independence, however, is that the UK's territorial constitution does not adequately recognize the plurinational character of the state.

In fact, in the wake of the referendum, there is substantial agreement amongst informed observers that reforms need to go beyond the transfer of additional powers to the Scottish Parliament and Scottish Government to include reforms to the territorial constitution more broadly. ${ }^{90}$ In this sense, the constitutional discontents underpinning support for independence

\footnotetext{
${ }^{88}$ Cf Mullen Independence Referendum (n 80) at 638.

${ }^{89}$ See further Tickell in this volume.

${ }^{90}$ See chapters by McEwen and Walker in this volume.
} 
may again be seen as part of the 'unfinished business' of devolution. ${ }^{91}$ Whilst devolution involved radical change at the peripheries, it left the central state apparatus largely unaltered and key constitutional assumptions - formally at least - intact. But where nationalists differ from unionists is in their deep pessimism about the reformability of the UK constitution. ${ }^{92}$

There are three problems in particular with the current territorial constitution. The issue raised most frequently by nationalists is the lack of security for institutions of Scottish selfgovernment, given the doctrine of Parliamentary sovereignty, ${ }^{93}$ and the lack of legal recognition of Scotland's right to self-determination - constitutional defects which were also identified by the architects of devolution. For instance, according to the Scottish Constitutional Convention, '[w]e do not believe that the sovereignty of the Scottish people can be satisfactorily protected in a constitutional settlement which establishes a Scottish Parliament within the UK unless the provisions of that settlement are entrenched. ${ }^{94}$ Far from entrenching the Scottish Parliament, however, the Scotland Act 1998 included an explicit statement of the right of the UK Parliament to continue to legislate for Scotland on devolved matters (section 28(7)), albeit subject to the understanding that, as a matter of convention, this power would not normally be exercised without the consent of the Scottish Parliament (the Sewel Convention).

\footnotetext{
${ }^{91}$ See Mitchell Devolution's Unfinished Business (n 54).

${ }^{92}$ See, eg, Sturgeon Bringing the Powers Home (n 14); G. Hassan 'The Making of the Modern SNP: From Protest to Power', in G. Hassan (ed) The Modern SNP: From Protest to Power (Edinburgh University Press 2009) 14.

${ }^{93}$ See Scotland's Future (n 17) at 336.

${ }^{94}$ Towards a Scottish Parliament (n 13) at 19 (and 19-21); see also Claim of Right (n 13) at para 4.8 and Epilogue; Scotland's Parliament; Scotland's Right (n 13) at 18 - 19.
} 
In fact, the standard response to complaints about lack of constitutional recognition is to point to constitutional practice which, it is claimed, embodies a strong political commitment to the permanence of devolution, and clear acknowledgment of the fact that Scotland is in control of its own constitutional destiny. Indeed - as the Scottish Constitutional Convention eventually came to accept ${ }^{95}$ - it can be argued that Scottish autonomy is just as well, if not better, protected under the UK's political constitution than in comparable written constitutional orders - the unusual (in comparative terms) willingness of the UK government to concede a referendum on independence being a case in point. ${ }^{96}$ Indeed, it might be argued that political commitment is more important than legal guarantees, since in the extreme and improbable political circumstances in which abolition of the Scottish Parliament might be contemplated, legal guarantees would be unlikely to save it.

All that accepted, however, political commitments lack the symbolic reassurance that legal entrenchment would deliver. In addition, the gap between the legal and political constitutions is not without practical significance. ${ }^{97}$ The reality of the abolition of the devolved Northern Ireland Parliament and the repeated suspension of the Northern Ireland Assembly (albeit in very different political circumstances) stands in stark counterpoint to claims that abolition of

\footnotetext{
${ }^{95}$ See Scotland's Parliament, Scotland's Right (n 13 ) at 18.

${ }^{96}$ See A. Tomkins 'Scotland's Choice, Britain’s Future' (2014) 130 LQR 215 at220.

${ }^{97}$ The resulting ambiguity over the constitutional status of devolution also has implications for the relationship between the Scottish Parliament and Government and the courts, in terms of how the latter approach questions concerning the scope of devolved competence, the review of devolved decision-making, and the validity of UK legislation encroaching upon devolved matters, all of which are important determinants of the extent of Scottish self-government in practice. For the difference that varying background assumptions about the constitutional status of devolution may make compare, eg, the speeches of Lord Rodger and Lord Hope in Martin and Miller $v$ Lord Advocate [2010] UKSC 10; and the speeches of Lord Hope and Lord Reed in AXA General Insurance Ltd v Lord Advocate [2011] UKSC 46.
} 
the Scottish Parliament is unthinkable. Less dramatically, the lack of legal enforceability of constitutional conventions creates a structural bias in favour of the UK Government's preferred interpretation in cases where the scope of the Sewel Convention is in dispute - as for example, in relation to the right of the Scottish Parliament to veto any proposed repeal of the Human Rights Act. ${ }^{98}$ And in relation to the independence referendum itself, while the UK government accepted the Scottish Government's political mandate to hold a referendum, it nevertheless disputed its legal right to do so. The resulting legal uncertainty had practical consequences in enabling the UK government to exert control over the terms on which the referendum took place, and makes the ability to hold a future referendum similarly uncertain. $^{99}$

In fact, amongst the recommendations of the Smith Commission, which was set up to agree proposals for further devolution to Scotland following the referendum, were that the Scottish Parliament and Scottish Government should be made permanent, and the Sewel Convention placed on a statutory footing. ${ }^{100}$ Provisions to give effect to these proposals have been included in the Scotland Bill which is, at the time of writing, being considered by the UK Parliament, and similar provisions are included in the draft Wales Bill. ${ }^{101}$ However, implementation has been accompanied by a narrative of impossibilism - ie, of the legal

\footnotetext{
${ }^{98}$ On which see, M. Elliott 'Could the Devolved Nations Block the Repeal of the Human Rights Act and the Enactment of a New Bill of Rights? Public Law for Everyone Blog, 12 May 2015; and 'The Scottish Parliament, the Sewel Convention and Repeal of the Human Rights Act: a Postscript' Public Law for Everyone blog, 28 September 2015; and I. Jamieson 'The Repeal of the Human Rights Act and the Sewel Convention in Scotland' Scottish Constitutional Futures Forum blog, 12 June 2015.

${ }^{99}$ See further Tickell in this volume.

${ }^{100}$ Report of the Smith Commission for Further Devolution of Powers to the Scottish Parliament (2014) paras 21 and 22 .

${ }^{101}$ Wales Office Draft Wales Bill (Cm 9144, 2015).
} 
ineffectiveness of any attempt at entrenchment, given the doctrine of Parliamentary sovereignty - and, somewhat contradictorily, by reluctance on the part of the legislative drafters to use language which can be read as being unambiguously intended to have binding legal effect. ${ }^{102}$ Moreover, although the Smith Commission report acknowledged 'the sovereign right of the people of Scotland to determine the form of government best suited to their needs,' and 'that nothing in this report prevents Scotland becoming an independent country in the future should the people of Scotland so choose, ${ }^{, 103}$ no attempt has been made to give this any legal expression. Indeed, an attempt by SNP MPs to amend the Scotland Bill to make it clear that the Scottish Parliament had the right to authorize another referendum was rejected. ${ }^{104}$ In other words, the gap between the political and the legal constitutions will remain.

The second problem with the current territorial constitution is its lack of attention to shared rule as a counterbalance to the dispersal of power through devolution. Mechanisms for shared rule are important, both to deal with the inevitable policy spill-overs, functional overlaps, and competence disputes that arise in any system of territorially-divided power, and also, as has been argued above, to take account of territorial differences on issues which remain reserved to the centre. However, as Nicola McEwen discusses in her chapter, ${ }^{105}$ devolution was accompanied by only weak and largely informal mechanisms for inter-

\footnotetext{
${ }^{102}$ At the time of writing, the provisions in clause 1 of the Scotland Bill on the permanence of the Scottish Parliament and Government have been strengthened, but still, in my view, contain scope for ambiguity; the provisions in clause 2, 'recognizing' the Sewel Convention, still do not, in my view, create a legal rule. 
governmental relations (IGR), and no reorganization at the centre to enhance territorial representation. $^{106}$

Despite recognition of the problem of shared rule - the IGR arrangements were criticized by both the Calman Commission and the Smith Commission ${ }^{107}$ - there have only been limited attempts to address it. Following the recommendations of the Smith Commission, negotiations are ongoing between the UK and Scottish Governments to improve intergovernmental working, and in particular to improve Scottish Government input into EU decision-making. However, calls for the basic principles of the IGR system to be enshrined in statute ${ }^{108}$ have so far gone unanswered. Reconstitution of the House of Lords as a territorial chamber has been mooted, but is not seriously in prospect, while the injection of an element of territorial representation into the House of Commons via the introduction of English Votes for English Laws (EVEL) is actually aimed at reducing the influence of Scottish (and Welsh and Northern Irish) MPs over legislation (directly) affecting England only. Similarly, arguments that matters affecting the constitutional framework of the UK as a whole - such as withdrawal from the EU or reform of human rights law - should be subject to parallel consent in all four parts of the UK, rather than simply governed by a UK-wide majority, have been rejected.

The basic difficulty in responding adequately to the problem of shared rule is one of constitutional asymmetry. In part, this refers to the asymmetrical nature of the devolution arrangements (and in particular, the fact that England has no devolved government), which

\footnotetext{
${ }^{106}$ The only explicitly territorial mechanisms at UK level - the Scotland, Wales, and Northern Ireland Offices, and their corresponding parliamentary select committees - predate devolution.

${ }^{107}$ Calman Commission (n 10) at part 4; Smith Commission (n 100) at foreword and paras $28-31$.

${ }^{108}$ See Scottish Parliament Devolution (Further Powers) Committee Changing Relationships: Parliamentary Scrutiny of Intergovernmental Relations, $8^{\text {th }}$ Report 2015 (Session 4), SP Paper 809.
} 
has allowed devolution to be regarded as a set of discrete and self-contained constitutional reforms, with no implications for the constitution as a whole. But the more fundamental problem is the asymmetry of the state itself: as MacCormick put it, 'there would be a severe democratic deficit in any blocking arrangement that enabled the two-elevenths [of the UK population] to protect their position against the nine., 109

The final problem with the current territorial constitution - and which is emphasized more by unionists than nationalists - is its lack of reciprocity. In part, this is also a problem of asymmetry and concerns the legitimacy problems and inherent instability caused by divergent devolution arrangements ${ }^{110}$ - and in particular, the perceived injustice resulting from the lack of any separate political representation for England. ${ }^{111}$ But it is also refers to the absence of any explicit mechanisms to tie Scotland - and the other devolved nations - into the Union. ${ }^{112}$ In the absence of any legally recognized right to self-determination, there is also no clear understanding of the limits to that right: for instance, how often and in what circumstances it might be legitimate to hold an independence referendum - nor any clear statement of the principles upon which the Union is based, which might be invoked to resolve disagreements about the appropriate territorial distribution of power.

\footnotetext{
${ }^{109}$ Questioning Sovereignty (n 36) at 195.

${ }^{110}$ Mitchell Unfinished Business (n 54).

${ }^{111}$ See A. Henderson et al 'National Identity or National Interest? Scottish, English and Welsh Attitudes to the Constitutional Debate' (2015) 86 Pol Q 265 at 268.

${ }^{112}$ See G. Brown My Scotland, Our Britain: a Future Worth Sharing (Simon \& Schuster 2014) ch 7 J. Gallagher The Day After Judgment: Scotland and the UK After the Referendum (Policy Scotland 2014); Bingham Centre for the Rule of Law A Constitutional Crossroads: Ways Forward for the United Kingdom (British Institute of International and Comparative Law 2015); Constitution Reform Group, Towards a New Act of Union: $a$ Discussion Paper (2015), available at <www.constitutionreformgroup.co.uk>.
} 
This aspect of the territorial constitution has been almost entirely ignored post-referendum. Reforms to the devolution arrangements in Scotland, Wales, and Northern Ireland are proceeding through discrete and unconnected processes, while reforms in England - EVEL and the misleadingly-named 'city devolution' programme ${ }^{113}$ - are in no way commensurate with the arrangements for self-government in the other parts of the UK. Any notion of an over-arching framework for devolution thus remains radically under-developed. ${ }^{114}$ The essential problem here is the continued dominance of a political rather than a constitutional logic to devolution. ${ }^{115}$ The problems of territorial governance being addressed through devolution have been viewed primarily through a political (and sometimes - as in the case of EVEL - a party political) lens, to be resolved as best suits local circumstances, with no concern for their overall coherence or long-term implications.

To adequately address these problems would require a root and branch overhaul of the territorial constitution probably including, as the Bingham Centre has recently argued, a written constitution. ${ }^{116}$ Yet such a prospect seems wholly unrealistic. In the first place, there appears to be no political appetite for anything other than piecemeal reform. Any attempt to 'crystallize" ${ }^{117}$ the territorial constitution would be a major change to the deep structure of the constitution, which values flexibility above all else. Such a radical departure would require

\footnotetext{
${ }^{113}$ See Cities and Local Government Devolution Bill 2015 - 16, available at:

<http://services.parliament.uk/bills/2015-16/citiesandlocalgovernmentdevolution.html>.

114 The Bingham Centre argues that key principles can be derived from the devolution case law, including the principle that 'while there are differences of detail between the three devolution regimes, they are nonetheless best seen as a single body of legislative reform for the United Kingdom, accompanied by a single body of case law.' Constitutional Crossroads (n 112) at 16. However, this is a highly contestable claim.

${ }^{115}$ See J. Mitchell Devolution in the UK (Manchester University Press 2009) at 220 - 222.

${ }^{116}$ Constitutional Crossroads (n 112) at 19

${ }^{117}$ Gallagher Day After Judgment (n 112).
} 
some precipitating constitutional impetus, which simply does not appear to be present. As before the independence referendum, ${ }^{118}$ the main focus of constitutional attention at UK level is now on issues other than the future of the Union - primarily, Britain's membership of the European Union and reform of human rights law - and the direction of travel is back towards, not away from, the traditional constitutional model.

Secondly, even if it were a realistic prospect, it is highly questionable whether a comprehensive constitutional resettlement would be desirable. The value of the political constitution lies not just in its flexibility but also in its (sometimes strategic) ambiguity, which allows competing understandings of the constitution to be maintained simultaneously without having to be finally resolved. ${ }^{119}$ The territorial constitution above all has operated as an 'incompletely theorized agreement'; ${ }^{120}$ it has been 'a protean concept, taking different forms in different places. $^{, 121}$ Any attempt to define and codify the Union therefore risks either being so bland and abstract as to be pointless, ${ }^{122}$ or else exposing rather than resolving territorial disagreement. It may also act as an obstacle to further evolution at a time when understandings of the territorial character of the state are in flux. ${ }^{123}$

\footnotetext{
${ }^{118}$ McHarg A Tale of Two Constitutions (n 55).

${ }^{119}$ See M. Foley The Silence of Constitutions: Gaps, 'Abeyances', and Political Temperament in the Maintenance of Government (Routledge 1989).

${ }^{120}$ Cass R. Sunstein 'Incompletely Theorized Agreements' (1995) 108 Harvard Law Review 1733.

${ }^{121}$ M. Keating 'Can the Union Be Saved From Unionists? Centre on Constitutional Change blog, 18 September 2015, <http://www.centreonconstitutionalchange.ac.uk/blog/can-union-be-saved-unionists〉.

${ }^{122}$ Brown My Scotland (n 112) at 195.

${ }^{123}$ On the value of constitutional 'unsettlement', see N. Walker 'Our Constitutional Unsettlement' [2014] PL 529.
} 
In these circumstances, evolutionary change - or "muddling through" ${ }^{, 124}$ - may be the best option on offer, and may eventually arrive at a stable equilibrium. For instance, the claimed impossibility of achieving legal entrenchment of the Scottish Parliament arguably underestimates the extent to which the doctrine of Parliamentary sovereignty has been qualified in recent years, ${ }^{125}$ and may therefore be further qualified in future, including as a result of devolution. Nevertheless, in an evolutionary constitution, there can be no certainty that any statutory statement of the permanence of the devolved institutions would have that effect. The UK constitution is thus, by its nature, resistant to explicit steering, and in that sense the territorial constitution may accurately be described as unreformable. Moreover, in the meantime, the management of territorial relations must remain a fundamentally political matter. While attitudes to the future of the Union remain deeply polarized, there will be an ever-present risk that political disagreement may explode into constitutional crisis, whether over issues such as the scope or exercise of devolved powers, broader constitutional questions such as EU withdrawal, or merely the direction of public policy.

\section{The constitution of an independent Scotland}

The final element of the constitutional case for independence presented it not merely as a means of allowing Scotland to escape from an unsatisfactory constitutional position within the UK, but, more positively, as an opportunity for constitutional renewal. In other words, the constitutional discontents animating the desire for independence go beyond the territorial constitution to encompass a more comprehensive critique of the UK's political system: its

\footnotetext{
${ }^{124}$ See C.E. Lindblom 'The Science of "Muddling Through"' (1959) 19 Public Administration Review 79.

${ }^{125}$ See eg $R v$ Secretary of State for Transport ex p Factortame (No 2) [1991] 1 AC 603; Thoburn v Sunderland CC [2003] QB 151; $R$ (Jackson) v Attorney General [2006] 1 AC 262; $R$ (HS2 Action Alliance Ltd) v Secretary of State for Transport [2014] UKSC 3.
} 
inadequate democracy; ${ }^{126}$ its lack of security for rights; and its over-weening executive power. ${ }^{127}$ Again, we see here a consistent thread between arguments for independence and arguments for devolution. According to the Claim of Right, 'the failure to provide good government for Scotland is a product not merely of faulty British policy in relation to Scotland, but of fundamental flaws in the British constitution. ${ }^{128}$ The Scottish Constitutional Convention thus sought not only decentralization of power from the UK to Scotland, but also to 'usher in a new way of politics that is radically different from the rituals of Westminster: more participative, more creative, less needlessly confrontational. ${ }^{129}$

In the case of independence, the constitutional innovation was to be a written constitution, in contrast to the UK's 'unwritten' constitution, which would be developed through an inclusive and participatory process by an independent constitutional convention. ${ }^{130}$ According to Nicola Sturgeon, 'the prospect of a Constitutional Convention and a written constitution are themselves positive reasons for voting Yes. ${ }^{131}$ This was particularly important as a way of emphasizing why the clean break entailed by independence would be more desirable than simply reforming the devolution settlement. It also served to underline the political differences between Scotland and the UK, being justified by reference both to the claimed existence of a distinct Scottish constitutional tradition (which could be more authentically

\footnotetext{
${ }^{126}$ Particular criticisms relate to the role of the unelected House of Lords, and the non-proportional nature of the House of Commons' electoral system.

${ }^{127}$ See, eg, Scottish Government Written Constitution (n 22) at paras $1.4-1.5$.

${ }^{128}$ Claim of Right (n 13) at para 1.2. See also paras 4.2, 4.4, 4.5, and epilogue.

${ }^{129}$ Scotland's Parliament, Scotland's Right(n 13) at p 9. See also B. Crick and D. Miller To Make the

Parliament of Scotland a Model for Democracy (John Wheatley Centre 1995).

${ }^{130}$ Scottish Government Written Constitution (n 22).

${ }^{131}$ Constitutional Future (n 59).
} 
realized in an independent state) and to the modernization and normalization of Scotland's governance arrangements. ${ }^{132}$

There are several possible responses to the constitutional renewal argument. One is to question the premise that independence is either a necessary or a sufficient condition for constitutional change. As to the former, Jackson argues that the nationalist critique of the shortcomings of the British state is ground in a New Left analysis ${ }^{133}$ which

does not seem to have been updated to take account of the large constitutional changes wrought by the Labour government of $1997-2010$... These fundamental steps towards making Britain a more plural, inclusive and democratic state regardless of whether they are ultimately far-reaching enough - suggest a flexibility and capacity for reform in British political institutions that is underrated by nationalist critics. $^{134}$

In addition, as Page points out in his chapter, the devolved institutions in Scotland already enjoy considerable organizational autonomy, which is set to increase further once the Scotland Bill is enacted. Undeniably, though, Scottish voters are not currently fully in control of their governance arrangements, which leaves them at risk of constitutional reforms which the majority do not support - such as EU withdrawal or human rights reform.

Viewed simply as an argument about where formal powers to undertake constitutional reform are situated, the constitutional renewal argument seems simply to be an example of the broader democratic case for independence. In fact, however, the point is a different one, namely that a new constitutional beginning would provide an opportunity and impetus for

\footnotetext{
${ }^{132}$ See eg Scotland's Future (n 17) at 332, $334-5$.

${ }^{133}$ Political Thought (n 33) at $50-52$.

${ }^{134}$ Political Thought (n 33) at 52.
} 
radical and comprehensive reimagining of governance arrangements that in practice is unlikely to occur in a continuing constitutional order - particularly one like the UK which, as discussed above, combines flexibility with a fundamental constitutional conservatism. Thus, while the path to a constitutional convention and permanent written constitution was clearly marked if Scotland had voted Yes to independence, ${ }^{135}$ it is very difficult to identify a similar prospect in the UK context. Although proposals have been made for the establishment of a UK constitutional convention, ${ }^{136}$ the issue is not, at least for the foreseeable future, seriously on the political agenda. In any case - and partly for the reasons discussed in the last section it would be a much more complex and challenging undertaking in a UK context compared with an independent Scotland. ${ }^{137}$

However, if independence would provide greater opportunities for constitutional reform, it does not follow that it would in fact produce substantially different outcomes. For instance, while the formal design of the Scottish Parliament included some significant innovations most importantly in relation to its voting system - the substantive implications for the conduct of government and politics in Scotland have been much more limited than

\footnotetext{
${ }^{135} \mathrm{~S} 33$ of the draft interim constitution required the Scottish Parliament to make provision, as soon as possible after Independence Day, for the establishment of an independent constitutional convention charged with the task of drawing up a written constitution - Scottish Government The Scottish Independence Bill: a Consultation on an Interim Constitution for Scotland (2014).

${ }^{136}$ Most notably by the House of Commons Political and Constitutional Reform Committee Do We Need a Constitutional Convention for the UK?, $4^{\text {th }}$ Report 2012-13, HC 371.

${ }^{137}$ Though this is not to suggest that a Scottish Constitutional Convention would not be without its challenges too. See generally S. Suteu 'Developing Democracy through Citizen Engagement: the Advent of Popular Participation in the United Kingdom's Constitution-Making' (2015) 4 Cambridge Journal of International and Comparative Law (forthcoming).
} 
expected. ${ }^{138}$ This is because proponents of a new politics underestimated the degree of political continuity that devolution in fact entailed. Given that independence would itself build upon devolution, there would again be substantial continuity at the level of the day-today operation of the constitution which might blunt the radical edge of any formal constitutional changes.

In any case, there were considerable elements of continuity in the constitutional arrangements proposed by the Scottish Government. For instance, its draft interim constitution would clearly have involved an evolutionary development of Scotland's current constitutional framework, rather than a revolutionary change. ${ }^{139}$ There were also some more surprising examples of constitutional conservatism, such as a commitment to retain the monarchy, and not to increase the size of the Scottish Parliament. Although these arrangements would all have been provisional, there was a clear danger of path dependency limiting the likelihood of more fundamental change being adopted in the permanent constitution.

Further, the idea that there is a distinctive Scottish constitutional tradition which could inform a new Scottish constitution is itself highly questionable. ${ }^{140}$ Political actors in Scotland frequently appeal to a claimed Scottish tradition of popular sovereignty as opposed to Parliamentary sovereignty, and this principle was to be enshrined in the interim constitution. ${ }^{141}$ However such a claim is both of dubious historical accuracy ${ }^{142}$ and of limited

\footnotetext{
${ }^{138}$ See eg P. Cairney 'Scotland's Future Political System' (2015) 86 Pol Q 217; and see Page in this volume. ${ }^{139}$ See A. McHarg 'A Constitution for an Independent Scotland: the Draft Scottish Independence Bill' Scottish Constitutional Futures Forum blog, 21 June 2014.

${ }^{140}$ For a contrary view see W.E. Bulmer 'The Emergent Scottish Constitutional Tradition: Scottish, Nordic and Global Influences', in Müller (ed) Scotland 2014 (n 46).

${ }^{141}$ Draft Scottish Independence Bill ss 2 and 3.

${ }^{142}$ See C. Kidd 'Sovereignty and the Scottish Constitution before 1707' (2004) Juridical Review 225.
} 
practical utility. Although it says something important about the location of constituent power within the state, it is not clear what further implications it has for the content of the constitution. Whilst the principle of popular sovereignty was invoked to justify the participatory constitution-making process that was envisaged, ${ }^{143}$ it is clear that in reality these proposals owed more to comparative experience than to indigenous constitutional practice.

Nevertheless, the near-certainty that an independent Scotland would have ended up with an entrenched written constitution ${ }^{144}$ would have been a significant departure from the UK constitutional tradition. In addition, the kind of constitution envisaged by the Scottish Government - not just 'a procedural framework for democratic participation' but one with 'an instrumental and transformative' role $^{145}$ - would have further accentuated the constitutional distance travelled. For Nicola Sturgeon, '[t]he constitution should ... set out the aspirations we have for our country and our vision for the future. ${ }^{146}$ The Scottish Government therefore proposed - albeit acknowledging that its voice would be only one amongst many - that the constitution should contain extensive rights guarantees, as well as various substantive commitments, for instance to a ban on nuclear weapons and the sustainable use of natural resources. ${ }^{147}$

In envisaging a heavily substantive constitution, though, the Scottish Government left itself open to charges of inappropriate politicization of the constitution, of over-judicialization, and

\footnotetext{
${ }^{143}$ Sturgeon Constitutional Future (n 59).

${ }^{144}$ The possibility that the process of drafting a permanent, written constitution would have failed cannot of course be excluded.

${ }^{145}$ Bulmer Scottish Constitutional Tradition (n 140) at 218.

${ }^{146}$ Sturgeon Constitutional Future (n 59).

${ }^{147}$ See Scottish Government Written Constitution (n 22) at para 1.10. A number of substantive commitments were also included in the draft Interim Constitution - Scottish Government Interim Constitution (n 135).
} 
of seeking illegitimately to bind future generations. It therefore sat uneasily with the claim that independence would enhance the democratic legitimacy of government in Scotland. The Scottish Government could also fairly be accused of complacency about the effectiveness of Scotland's existing democratic institutions, proposals for institutional and democratic reform being noticeably absent from its constitutional agenda. ${ }^{148}$ However, there were voices during the referendum debate calling for more radical constitutional reforms, ${ }^{149}$ and the constitutional convention would have provided an institutional platform for the articulation of such proposals - as well as for a broader debate about the appropriate form and content of the constitution.

\section{Conclusion}

The aim of this chapter has been to show that, despite the lack of clear evidence of constitutional discontent in Scotland ahead of the 2014 referendum, there was - and continues to be - a coherent constitutional case to be made for independence. However, certain tensions within the independence case, and the contestable nature of some of its assumptions, mean that it can be regarded as persuasive, but not incontrovertible. Independence may reasonably be considered to be an answer to the problems identifiable in Scotland's current constitutional position, but it cannot be regarded as the answer.

The constitutional case for independence is also inescapably a nationalist one - however uncomfortable some Yes supporters may have been with that idea. It is a nationalist case because it hinges on the acceptance of the relevance of Scotland as a self-determining political community. Paradoxically, however, what allowed the Yes campaign to play down its explicitly nationalist character is precisely the non-controversial nature of that claim in the

\footnotetext{
${ }^{148}$ Cairney Scotland's Future Political System (n 138).

${ }^{149}$ See Bulmer Scottish Constitutional Tradition (n 140) at $218-219$.
} 
Scottish context. That fundamental point was conceded when the Scottish Parliament was established in 1999. Indeed, as I have also sought to demonstrate, there is a striking similarity between the constitutional arguments used to justify devolution and those used in support of independence.

In part, this may have been a matter of attempting to piggy-back support for independence upon the popularity of devolution. However, more fundamentally, I would argue that it also indicates that devolution did not fully answer the constitutional problems that its proponents identified. From this perspective, the apparent public satisfaction with Scotland's constitutional arrangements prior to 2011 may perhaps suggest quiescence rather than consent; in other words, it may have been attributable to the relatively favourable political and economic conditions during the first decade of devolution - political alignment between Westminster and Holyrood and generous public spending provision - rather than to a more fundamental resolution of the underlying constitutional discontents. ${ }^{150}$

In the wake of the independence referendum, political circumstances are very different and when combined with evidence about voters' primarily instrumental reasons for rejecting independence - cannot give supporters of the Union much comfort. As I have sought to argue in this chapter, finding a satisfactory constitutional home for Scotland within the Union is not likely to be easy. At present the constitutional direction of travel therefore appears to be towards greater autonomy for Scotland rather than towards any stronger cleaving to the Union. Only time will tell whether Scottish voters are prepared to take the further step towards independence; whether their attitude becomes one of 'why not?' or rather 'why bother?'.

\footnotetext{
${ }^{150}$ Cf Mitchell Unfinished Business (n 54) at 470, although he is talking about constitutional dissatisfaction in England.
} 